\title{
Erratum: First Measurements of Fuel-Ablator Interface Instability Growth in Inertial Confinement Fusion Implosions on the National Ignition Facility [Phys. Rev. Lett. 117, 075002 (2016)]
}

C. R. Weber, T. Döppner, D. T. Casey, T. L. Bunn, L. C. Carlson, R. J. Dylla-Spears, B. J. Kozioziemski,

A. G. MacPhee, A. Nikroo, H. F. Robey, J. D. Sater, and V. A. Smalyuk

(Received 21 September 2016; published 7 October 2016)

DOI: 10.1103/PhysRevLett.117.159902

The original Letter inadvertently omitted references to the first use of the term "feedthrough" in Rayleigh Taylor and inertial confinement fusion contexts [1,2].

[1] K. O. Mikaelian, Phys. Rev. A 28, 1637 (1983).

[2] K. O. Mikaelian, Phys. Rev. A 42, 3400 (1990). 